\title{
Coal As the National Energy Supplier Forward: What are Policies to be Prepared?
}

\author{
Hanan Nugroho² \\ Ministry of National Development Planning/BAPPENAS
}

\begin{abstract}
Indonesia's energy security is critical, coal which is expected to be the backbone of national energy supply also faces considerable challenges. To overcome this, it is necessary to formulate a policy of production control, export restrictions, as well as concerning the economy, environment and infrastructure of coal. The paper recommends that: (i) Develop depletion policies to control coal production, (ii) Implement strict discipline in granting mining permits, (iii) Reduce coal exports through export taxes, (iv) Develop more appropriate DMO (domestic market obligation) policies ( $\mathrm{v}$ ) Utilizing coal as energy to drive activities and provide added value to the domestic economy, (vi) Increasing the application of clean coal technology, and (vii) Accelerating the development of transportation, storage, and utilization of coal to serve the needs of domestic demand.
\end{abstract}

Keywords: Energy, Coal Policy

1 This manuscript is part of the study "Menyiapkan Batubara Sebagai Tulang Punggung Pasokan Energi Nasional" conducted by Tim Analisis Kebijakan BAPPENAS in 2015 where the author is the main researcher.

2 Hanan Nugroho is a Principal Planner at Ministry of National Development Planning/BAPPENAS. Email address: nugrohohn@ bappenas.go.id 


\section{Batu Bara Sebagai Pemasok Energi Nasional ke Depan: Apa yang Perlu Disiapkan?}

\section{Pendahuluan}

Kebutuhan energi Indonesia terus meningkat seiring tumbuhnya ekonomi, jumlah penduduk, urbanisasi dan perubahan gaya hidup yang semakin banyak menggunakan energi. Indonesia diproyeksikan menjadi salah satu kekuatan ekonomi besar dunia, namun proyeksi ini dihadapkan pada tantangan kecukupan pasokan energi. Beberapa studi menyatakan ketahanan energi Indonesia kritis. ${ }^{3}$

Peraturan Pemerintah 79/2014 tentang Kebijakan Energi Nasional mengarahkan agar dapat memenuhi: (i) penyediaan energi primer sekitar 400 MTOE (2025) dan 1.000 MTOE (2050), serta (ii) kapasitas pembangkit listrik sekitar 115 GW (2025) dan $430 \mathrm{CW}$ (2050). PP sama mengarahkan pangsa batubara minimal 30\% dan 25\% dalam bauran penyediaan energi primer nasional pada tahun 2025 dan 2050.

Target pangsa batubara yang cukup besar dalam pemasokan energi nasional tersebut masuk akal mengingat cadangan batubara Indonesia yang besar dibandingkan cadangan bahan bakar fosil lainnya. Di sisi lain, produksi minyak bumi Indonesia terus menurun, digantikan impor minyak mentah dan produk minyak yang meningkat. Produksi gas bumi yang juga menurun masih harus digunakan untuk memenuhi kontrak-kontrak ekspor jangka panjang.

Walaupun batubara diharapkan menjadi tulang punggung pasokan energi nasional, kesiapannya menghadapi sejumlah tantangan. Di antaranya adalah karena produksi batubara yang tumbuh cepat, dan sebagian besar dari produksi tersebut diekspor. Indonesia diproyeksikan akan menggunakan banyak tambahan batubara terutama untuk memasok pembangkit-pembangkit listrik. Produksi batubara yang tumbuh pesat, selain karena cadangannya yang relatif besar dan teknologi eksploitasinya yang relatif sederhana, adalah karena dorongan memperoleh pendapatan cepat dari pengusaha maupun penguasa. Tingkat eksploitasi yang tinggi dikhawatirkan mengurangi kemampuan pasokan batubara untuk dalam negeri ke depan. Upaya membawa batubara dari lokasi-lokasi keterdapatannya ke lokasi-lokasi permintaannya terhambat langkanya sarana dan prasarana angkutan/ penyimpanan batubara.

Makalah ini mempelajari permasalahan/tantangan yang dihadapi industri batubara Indonesia untuk dapat memenuhi tugasnya sebagai tulang punggung penyediaan energi nasional ke depan. Berdasarkan pemahaman dan analisis yang dilakukan, makalah ini menyajikan beberapa Rekomendasi Strategi/Kebijakan termasuk mengenai: Produksi, Ekspor, Pemanfaatan Dalam Negeri, Pengurasan (Depletion Policy) dan Perizinan (Licensing). Penyusunan makalah kebijakan ini telah dilakukan dengan garis besar pekerjaan: (i) Mempelajari statistik, peraturan perundangan serta berbagai studi sebelumnya mengenai pembangunan batubara Indonesia, (ii) Survai mengenai pengusahaan batubara Indonesia4, (iii) Wawancara mengenai kebijakan pengembangan batubara Indonesia, serta (iv) Analisis dan pengembangan rekomendasi. 3 Misalnya sebagai yang dikemukakan oleh laporan tahunan World Energy Council (World Sustainability Index) maupun World
Energy Forum (Global Energy Architecture Performance Index Report).

${ }^{4}$ Survai lapangan dilakukan di PLTU Suralaya (Jawa Barat) dan PT Tambang Bukit Asam (Sumatera Selatan). 


\section{Pembangunan Batubara Indonesia: Data dan Tantangan}

\subsection{Perkembangan Produksi, Ekspor dan Konsumsi Dalam Negeri}

Produksi batubara di Indonesia dilakukan oleh BUMN, perusahaan swasta asing/domestik maupun perusahaan skala kecil, termasuk koperasi berdasarkan perjanjian Kontrak Karya, Perjanjian Karya Pengusahaan Pertambangan Batubara (PKP2B) maupun Izin Usaha Pertambangan yang diberikan oleh Pemerintah Pusat, Pemerintah Propinsi maupun Pemerintah Kabupaten/Kota.

Walaupun cadangan batubara Indonesia tidak besar, namun produksinya relatif banyak, sekitar 5,5 persen produksi dunia atau urutan kelima produsen batubara terbesar dunia ${ }^{5}$. Produksi didominasi kalori rendah hingga sedang, mencerminkan cadangan batubara Indonesia yang didominasi lignite dan sub-bituminous.

Pada awal 1990-an produksi batubara Indonesia tidak sampai 10 juta ton/ tahun $^{6}$, dihasilkan oleh BUMN PT Bukit Asam dari tambang di Muara Enim (Sumsel) dan Sawah Lunto (Sumbar). Produksi meningkat tajam akibat perkembangan teknologi PLTU dan diterapkannya sistem perijinan PKP2B terutama di Kalimantan. Sebagian besar produksi adalah untuk diekspor, menjadikan Indonesia pengekspor batubara terbesar di dunia7. Awalnya, tujuan ekspor batubara Indonesia adalah negara industri Asia Timur (Jepang, Korea Selatan, Taiwan), belakangan juga ke Cina dan India. Di Jepang batubara Indonesia digunakan di PLTU, untuk peleburan baja dan logam lainnya. Di Cina dimanfaatkan untuk bahan bakar pabrik, pembangkitan listrik dan sebagian disimpan untuk stock.

Gambar 1. Data dan perbandingan mengenai Batubara Indonesia

\section{Cadangan Batubara Dunia (2010)}

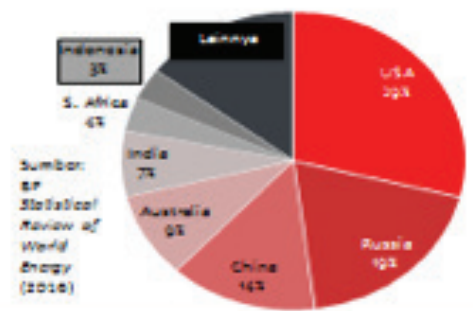

Produksi, Ekspor, Konsumsi DN wate rom

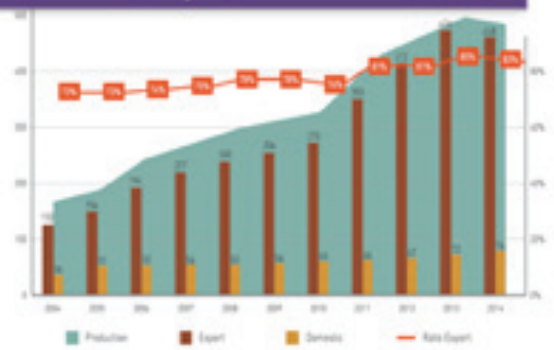

\section{Perbandingan Prodıksi dan Konsumsi Batubara Dunia}

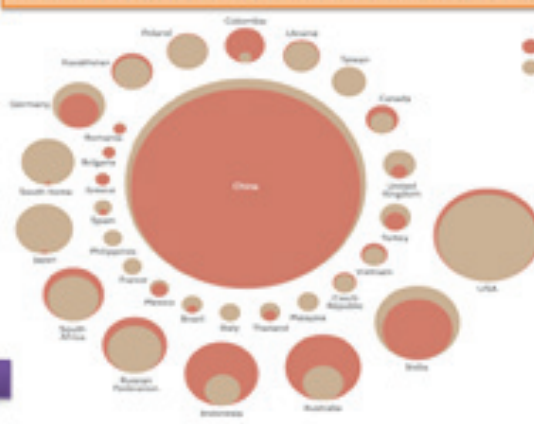

* Cadangan (reserves) batubara Indonesia tidak besar, hanya sekitar 3 persen cadangan dunia. Cadangan tersebar tidak merata, sebagian besar diKalimantan dan Sumatra.

* Produksibatubara Indonesia juga relatif tidak besar, namun Indonesia adal ah pengekspor batubara terbesar didunia... 
Di dalam negeri (yang mengkonsumsi hanya sekitar 10-25 persen produksi), batubara paling banyak digunakan untuk PLTU, baik milik PT Perusahaan Listrik Negara (PT PLN) maupun swasta (Independent Power Producers/IPP). Pangsa PLTU adalah sekitar 50 persen dari "power mix" nasional (21.755 MW dari 43.457 MW $^{8}$ ). Namun, sebagian besar (sekitar 90 persen) dari PLTU yang terpasang itu berada di sistem Jawa-Bali ${ }^{\text {. }}$

Di Jawa terdapat sejumlah PLTU berkapasitas besar, antara lain PLTU Suralaya 1-8 (4.025 MW) dan PLTU Paiton PLN-Swasta (4.725 MW'10). Upaya menyediakan listrik di Jawa-Bali dengan mengandalkan pada PLTU Batubara masuk akal dalam pengertian PLTU Batubara dapat menghasilkan daya listrik besar (sekaligus dapat berfungsi sebagai base load) yang dibutuhkan Jawa-Bali sebagai pemakai listrik dominan di Indonesia. Kapasitas pembangkitan listrik yang besar tersebut dapat disalurkan ke pemakai karena telah dibangunnya infrastruktur transmisi, distribusi, maupun pemindahan tegangan (gardu induk/distribusi) yang relatif baik di JawaBali.

Di luar Jawa-Bali, PLTU juga semakin banyak. PLTU dianggap sebagai pilihan yang murah untuk melayani permintaan listrik yang meningkat pesat, termasuk untuk melayani daerah-daerah terpencil yang belum terjangkau aliran listrik. Adanya program "10.000 MW" serta "35.000 MW" meningkatkan permintaan batubara yang jauh lebih besar dari yang selama ini telah coba dipenuhi di Tanah Air.

Selain untuk PLTU, batubara di Indonesia digunakan sebagai bahan bakar industri, khususnya yang relatif lahap energi seperti semen, kertas, tekstil, dan metalurgi. Pemakaian batubara pada beberapa industri, misalnya tekstil, dapat bersifat "price-sensitive", dipengaruhi oleh harga BBM. Batubara juga diolah untuk menjadi briket. Di Muara Enim, Tarahan dan Gresik di antaranya, telah dibangun pabrik briket sebagai upaya untuk mengurangi pemakaian minyak tanah (kerosene). Namun upaya memasarkan briket tersebut kurang berhasil, terutama setelah pemerintah mempopulerkan penggunaan LPG.

\subsection{Aspek Teknologi Pemanfaatan}

Batubara memiliki kandungan panas (kalori) berbeda-beda. Untuk volume batubara yang sama, akan disukai yang kandungan panasnya lebih tinggi karena menguntungkan tidak saja dalam pembakarannya namun juga dalam pengangkutannya. Upaya meningkatkan kalori batubara dapat dilakukan dengan menghilangkan mengurangi kadar air, mencampurnya (blend) dengan batubara lain dengan kalor lebih tinggi, mencampurnya dengan bahan bahan cair (misalnya minyak tanah), dsb.

UBC (upgraded brown coal) adalah upaya untuk menaikkan kadar panas batubara, yang dilakukan dengan mengurangi kadar air pada batu bara kalori rendah. Di Indonesia, teknologi UBC sedang dipraktekkan skala kecil di Palimanan (Jawa Barat) oleh Tekmira dan Kobe Steel. Riset serupa juga dilakukan di wilayah pertambangan PT Arutmin di Tanah Bumbu (Kalimantan Selatan). Riset mengenai UBC di Indonesia merupakan pelopor riset serupa di dunia, namun sampai sekarang belum sampai tahap komersial.

CTL (Coal to Liquid) atau pencairan batubara (coal liquefaction) memanfaatkan teknologi untuk mencairkan batubara, menghasilkan "BBM Sintetis" yang dapat digunakan sebagaimana halnya BBM. Teknologi ini telah dikembangkan secara komersial, yang menonjol adalah oleh Sasol (South African Coal Oil and Gas Corporation) di Afrika Selatan, dimana "BBM Sintetis" dari batubara tersebut telah digunakan secara luas. Studi pendahuluan untuk melihat kemungkinan penerapan

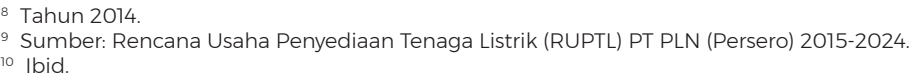


teknologi CTL telah dilakukan di Indonesia, namun upaya untuk mewujudkannya belum dilakukan serius.

Batubara juga dapat diubah ke bentuk gas atau menghasilkan gas (methane). Ini bukanlah hal/teknologi baru, karena telah dipraktekkan sejak 2 abad yang lalu, dan pernah dimanfaatkan di Indonesia untuk gas kota. Belakangan, Tekmira bekerja sama dengan PT PLN dan PT Coal Gas Indonesia membangun pilot plant gasifikasi batubara untuk Pembangkit Listrik Tenaga Diesel (PLTD) dengan maksud mengurangi penggunaan BBM. Namun, beberapa pilot plant yang dilakukan tersebut belum berpindah ke penerapan secara massal/komersial.

CBM (Coal Bed Methane) CBM adalah gas alam yang dihasilkan/terdapat karena proses kimia dan fisika-pada kedalaman tambang batubara". Produksi CBM terbesar di dunia adalah Amerika Serikat, dimana CBM telah memiliki pangsa sekitar 10 persen dari gas bumi yang dikonsumsi di sana. Indonesia memiliki cadangan CBM yang cukup besar, namun pemanfaatannya baru sebatas riset.

\subsection{Ekonomi}

Produksi batubara yang tumbuh pesat di Indonesia, selain karena cadangan yang besar dan teknologi eksploitasinya yang sederhana adalah karena dorongan memperoleh pendapatan cepat serta langkanya kebijakan yang membatasi produksi.

Produksi batubara memberikan manfaat ekonomi kepada Pemerintah (Pusat dan Daerah) dalam bentuk iuran tetap maupun iuran produksi. Termasuk iuran tetap adalah PBB (Pajak Bumi \& Bangunan) yang dikenakan dalam tahap eksplorasi maupun eksploitasi, yang besarannya relatip tetap. Iuran produksi (royalti) --dalam perkembangannya-- bervariasi tergantung pada besaran produksi, tarif (persentase) royalti, kandungan kalori, maupun cara penambangan batubara yang dilakukan (dengan menggunakan penambangan open pit atau under ground).

Royalti dari kegiatan pertambangan batubara dimasukkan ke dalam APBN sebagai Pendapatan Negara Bukan Pajak (PNBP) dari "pertambangan mineral dan batubara". Ketika PNBP Migas, khususnya minyak bumi menunjukkan penurunan, PNBP batubara menunjukkan angka yang cukup besar (2007). Produksi batubara yang terus meningkat diiringi dengan harga batubara yang tinggi (misalnya dalam kurun 2010-2012) membuat PNBP batubara terlihat sangat besar. Di kalangan pemerintah terdapat pandangan bahwa batubara layak untuk menjadi sumber PNBP yang di masa depan dapat menggantikan peran minyak dan gas bumi.

PNBP dari royalti yang diperoleh pemerintah pusat tidak langsung didistribusikan sebagai belanja pemerintah pusat, namun sebagian besar dibagikan ke daerah lokasi pertambangan dan sekitarnya sebagai dana bagi hasil (DBH). Daerah penghasil batubara seperti Kalimantan Timur dan Kalimantan Selatan serta Kabupaten/Kota di propinsi-propinsi tersebut memperoleh $\mathrm{DBH}$ bagi hasil yang cukup besar dan dimasukkan sebagai APBD.

\subsection{Lingkungan}

Aspek lingkungan dari pemakaian batubara menjadi sorotan karena, dibandingkan bahan bakar fosil lainnya batubara lebih "kotor" baik dalam pembakaran maupun transportasinya. Biaya pemakaian batubara sebagai bahan bakar pembangkitan listrik memang lebih murah dibandingkan pembangkit termal lainnya maupun yang bersumber dari energi terbarukan, namun pembakaran batubara menghasilkan emisi gas rumah kaca $\left(\mathrm{CO}_{2}\right)$ maupun "abu terbang" (fly ash) dalam jumlah cukup besar, yang dari segi lingkungan tidak sehat.

\footnotetext{
"Juga dikenal, misalnya di Australia sebagai CSG (coal seam gas). Di Australia banyak ditemukan di wilayah Queensland (bukan di daerah kaya tambang Australia Barat), sudah dimulai diproses menjadi LNG, dan diproyeksikan Australia akan menjadi eksporter LNG besar di dunia dari CSC ini.
} 
Permasalahan lingkungan dari batubara sesungguhnya telah dimulai sejak penambangannya. Penambangan yang tidak mengindahkan kaidah-kaidah "good mining practices" memberikan dampak kerusakan lingkungan yang luas di sekitar wilayah pertambangan, misalnya dalam bentuk kubangan bekas tambang yang tidak direklamasi. Kerusakan wilayah-wilayah sungai yang dilintasi angkutan batubara, termasuk kepadatan arus lalulintasnya telah menjadi di sungai Mahakam, Barito, Musi, dsb.

Indonesia mengikuti berbagai konvensi internasional mengenai lingkungan dan perubahan iklim, termasuk janji untuk menurunkan emisi gas rumah kaca sebear 26 persen dan 41 persen pada tahun $2020^{12}$. Pembakaran batubara, termasuk yang akan dihasilkan dari program-program pemerintah untuk membangun PLTU skala besar akan meningkatkan emisi gas rumah kaca Indonesia.

\section{Arah dan Rencana Pengembangan Batubara}

PP 79/2014 Pasal 10 mengamanatkan “Ketersediaan Energi untuk kebutuhan nasional dipenuhi dengan ... (d) mengurangi ekspor Energi fosil secara bertahap terutama gas dan batubara serta menetapkan batas waktu untuk memulai menghentikan ekspor". Pasal 11 ayat 2.d. mengamanatkan agar "menggunakan batubara sebagai andalan pasokan Energi nasional".

Mengenai pemanfaatan batubara PP 79/2014 mengamanatkan "pemanfaatan Sumber Energi batubara untuk ketenagalistrikan dan industri" (Pasal 12.1.h). Dalam pasal yang lain diamanatkan "peningkatan pemanfaatan batubara kualitas rendah untuk pembangkit listrik tenaga uap mulut tambang, batubara tergaskan (gasified coal) dan batubara tercairkan (liquified coal); dan "peningkatan pemanfaatan batubara kualitas menengah dan tinggi untuk pembangkit listrik dalam negeri" (Pasal 18 ayat 2 d. dan e.). PP 79/2014 juga menekankan pentingnya pengembangan infrastruktur batubara dengan mengamanatkan "mengembangkan infrastruktur pendukung industri batubara yang meliputi transportasi, stockpiling, dan blending untuk mewujudkan pasar yang efisien dan dapat mensuplai kebutuhan dalam negeri secara terus menerus" (Pasal 18. 2. b).

Pengaturan ekspor batubara sesungguhnya telah terdapat dalam UU No. 4/2009 tentang Pertambangan Mineral dan Batubara yang mengamanatkan bahwa "dalam rangka mendukung pembangunan nasional yang berkesinambungan, tujuan pengelolaan pertambangan mineral dan batubara adalah menjamin tersedianya mineral dan batubara sebagai bahan baku dan/atau sumber energi untuk kebutuhan dalam negeri" (Pasal 3 ayat c), dan "untuk kepentingan nasional, Pemerintah setelah berkonsultasi dengan Dewan Perwakilan Rakyat Republik Indonesia dapat menetapkan kebijakan pengutamaan mineral dan/atau batubara untuk kepentingan dalam negeri, dan pada ayat (2) bahwa kepentingan nasional sebagaimana dimaksud pada ayat (1) dapat dilakukan dengan pengendalian produksi dan ekspor" (Pasal 5 ayat 1).

UU No. 4/2009 sering ditafsirkan sebagai "melarang ekspor bahan mentah", namun hal ini belum diterapkan/berdampak pada ekspor batubara Indonesia. Pasal 102 UU tersebut mengamanatkan " Pemegang IUP dan IUPK wajib meningkatkan nilai tambah sumber daya mineral dan/atau batubara dalam pelaksanaan penambangan, pengolahan dan pemurnian, serta pemanfaatan mineral dan batubara. Sementara itu Pasal 103 mengamanatkan, (1) "Pemegang IUP dan IUPK Operasi Produksi wajib melakukan pengolahan dan pemurnian hasil penambangan di dalam negeri", dan (2) "Pemegang IUP dan IUPK sebagaimana dimaksud pada

\footnotetext{
12 Rencana Aksi Nasional (Peraturan Presiden No. 61 Tahun 2011) berisi serangkaian tindak lanjut untuk merealisasikan "janji" Presiden Susilo Bambang Yudhoyono bahwa Indonesia akan menurunkan emisi gas rumah kacanya sebesar 26 persen pada tahun 2020 tanpa bantuan internasional, dan targetnya akan ditingkatkan sampai 41 persen bila ada bantuan internasional.
} 
ayat (1) dapat mengolah dan memurnikan hasil penambangan dari pemegang IUP dan IUPK lainnya."

Rencana Pembangunan Jangka Menengah Nasional (RPJMN) 2015-2019 tidak secara langsung menetapkan pengurangan ekspor batubara, namun menetapkan penurunan target produksi batubara, yaitu dari 425 juta (2015) menjadi 400 juta ton (2019). Sasaran produksi batubara ini tidak dilengkapi dengan perkiraan pemanfaatan batubara di dalam negeri maupun perkiraan ekspor yang akan dilakukan. Di samping sasaran produksi batubara, RPJMN 2015-2019 juga menetapkan sasaran pemanfaatan batubara di dalam negeri (DMO: domestic market obligation) yang meningkat dari 24 persen pada tahun 2014 menjadi 60 persen pada tahun $2019 . .^{3}$

Sebuah rencana jangka panjang ${ }^{14}$ memperlihatkan rencana produksi, penjualan domestik dan ekspor batubara Indonesia hingga tahun 2050. Diprediksi bahwa produksi batubara akan menurun dalam jangka pendek, namun dalam jangka panjang terus meningkat. Mengikuti kecenderungan produksi jangka panjang, pemakaian batubara di dalam negeri terus meningkat. Sebaliknya, ekspor dalam jangka panjang diproyeksikan akan lebih rendah dibandingkan pemakaian dalam negeri.

\section{Temuan, Analisis dan Pengembangan Kebijakan}

Data cadangan (reserves), produksi, ekspor, serta konsumsi dalam negeri dari batubara Indonesia memperlihatkan gejala yang tidak sehat dari segi ketahanan energi. Cadangan batubara Indonesia tidak besar dibandingkan yang dimiliki Cina, Amerika Serikat, dsb., namun batubara yang diproduksi terlalu besar. Juga, porsi ekspor batubara Indonesia (sekitar 70-80 persen dari produksi) adalah terlalu besar untuk sebuah negara yang mengalami permasalahan kekurangan pasokan energi di dalam negeri. Dibandingkan negara-negara yang memiliki cadangan dan produksi batubara lebih besar, Indonesia adalah "anomali" karena menggunakan sebagian besar produksinya untuk diekspor.

Darisisi ketahananenergi, baik tingkat produksi maupun pangsa ekspor batubara Indonesia perlu dikritisi. Produksi yang dilepas tumbuh cepat, apakah karena Indonesia belum mengembangkan kebijakan pengendalian produksi batubara? Ekspor yang sangat besar, apakah karena Indonesia tidak membutuhkan batubara untuk memperkokoh ketahanan energinya sendiri, sekaligus meningkatkan nilai tambah ekonomi di dalam negeri? Atau belum melakukan pengendalian ekspor yang tepat? Bagaimana kaitan antara produksi dengan tingkat pengurasan yang dapat ditoleransi, apakah kebijakan yang telah dikembangkan mengenai hal ini?

Walaupun dari segi ketahanan energi batubara diharapkan menjadi tulang punggung pasokan energi nasional ke depan, namun kesiapannya menghadapi sejumlah tantangan. Kebijakan yang berkaitan dengan produksi, pemakaian dalam negeri, ekspor maupun pemberian izin (licensing) perlu diarahkan lebih tepat untuk memenuhi harapan bagi peran batubara tersebut.

\subsection{DMO dan Permintaan Dalam Negeri}

Penerapan kebijakan DMO akan bermanfaat untuk menjamin terpenuhinya kebutuhan batubara dalam negeri. Namun penerapan kebijakan tersebut oleh pemerintah Indonesia belum lama dimulai, dan masih terbatas hanya untuk menjamin ketersediaan batubara di dalam negeri untuk jangka pendek. Bagaimana menjamin ketersediaan pasokan batubara Indonesia untuk memenuhi kebutuhan batubara dalam jangka panjang (hingga 2050) merupakan hal yang penting untuk dikembangkan kebijakannya. 
Kewajiban untuk memasok pasar dalam negeri (DMO) batubara ${ }^{15}$ akan sulit atau tidak mungkin dipenuhi bila tingkat produksi batubara tidak diturunkan. Dengan tingkat produksi yang tinggi dan pangsa ekspor yang sangat besar sasaran peningkatan DMO, seperti yang ditargetkan dalam RPJMN 2015-2019 hampir mustahil dapat dipenuhi. Walaupun RPJMN 2015-2019 telah tepat dengan mengarahkan penurunan produksi batubara, kami menemukan masih terdapat "ketidakkonsistenan" antara sasaran produksi tersebut dengan target DMO. Berdasarkan data kebutuhan batubara untuk pembangkitan listrik serta industri, analisis kami menunjukkan target DMO sebesar 60 persen pada tahun 2019 tidak akan tercapai, tanpa melakukan pengurangan terhadap produksi batubara nasional secara lebih "terjal".

Untuk mengamankan pasokan batubara dalam negeri dalam jangka panjang, kebijakan DMO yang mendasarkan pada besaran produksi dalam negeri perlu diubah. Penerapan kebijakan DMO sekarang tidak dapat mencegah batubara untuk tidak dieksploitasi secara besar-besaran dalam waktu singkat, termasuk menimbulkan masalah-masalah lingkungan dalam eksploitasinya.

Kebijakan DMO ke depan mesti lebih menekankan pada pemenuhan kebutuhan dalam negeri sebagai prioritas pertama, bukan sebagai persentase dari produksi. Produksi, yang diupayakan berada di atas kebutuhan domestik, tetaplah harus dikendalikan berdasarkan cara pengendalian yang (akan) ditetapkan, termasuk misalnya kebijakan mengenai pengurasan (depletion policy). Ekspor dapat dilakukan bila selisih antara kemampuan berproduksi dengan kewajiban memenuhi kebutuhan dalam negeri cukup besar untuk dapat memenuhi permintaan ekspor tersebut. Karena cadangan batubara Indonesia cukup besar untuk dapat memenuhi kebutuhan dalam negeri, impor batubara diusahakan tidak perlu ada.

\subsection{Pembatasan/ Pengendalian Ekspor}

Tujuan dari pembatasan ekspor adalah untuk mengamankan ketersediaan batubara di dalam negeri jangka panjang. Pembatasan ekspor, dalam jangka pendek, akan mengurangi pendapatan negara maupun pengusaha pertambangan, termasuk kemungkinan pengurangan tenaga kerja. Dalam jangka panjang, pembatasan ekspor akan memberikan keuntungan, terutama bagi generasi mendatang.

Kebijakan pembatasan ekspor dapat juga dimanfaatkan untuk mencapai tujuan non-ekonomi seperti perlindungan terhadap lingkungan dan konservasi sumber daya alam. Larangan ekspor lazimnya dilakukan untuk tujuan non-ekonomi, sedangkan pajak ekspor lebih berorientasi pada pencapaian tujuan ekonomi.

Bagaimanapun, dalam hal suatu komoditas sudah diperdagangkan secara internasional, kemudian sama sekali melarang ekspornya akan sulit dilakukan, karena hal ini bertentangan dengan prinsip perdagangan bebas yang dikemukakan Organisasi Perdagangan Dunia (World Trade Organization, WTO). Walaupun demikian, terdapat kemungkinan bahwa pelarangan ekspor secara terbatas dapat dilakukan.

Beberapa butir dalam Artikel XX dari GATT (General Agreement on Tariffs and Trade) tentang "Pengecualian Umum" dapat dijadikan pijakan untuk pengendalian ekspor batubara. Di antaranya bahwa kegiatan pertambangan yang dilakukan secara besar-besaran untuk memenuhi permintaan pasar internasional dapat menimbulkan kerusakan lingkungan dan bahwa konservasi sumberdaya alam yang tak terbarukan dapat efektif dilakukan melalui pembatasan produksi dan konsumsi/ekspor. Dengan demikian pembatasan ekspor dapat dilakukan dimulai dari identifikasi wilayah-wilayah dimana kegiatan pertambangannya (termasuk

${ }^{15}$ Berdasarkan persentase tertentu dari produksi. Target DMO yang relatif rendah masih mungkin tidak tercapai bila proyekproyek yang akan memanfaatkan batubara (misalnya PLTU) tertunda atau batal pembangunannya. 
pengangkutannya) dapat dikategorikan telah mengganggu atau mengakibatkan kerusakan pada lingkungan. Penetapan wilayah dalam kategori ini dapat dilakukan oleh instansi pemberi izin (license grantor) bekerja sama dengan instansi lainnya yang berkaitan dengan pengelolaan lingkungan.

Kebijakan penerapan pajak ekspor -dalam kasus batubara di Indonesiamungkin ditentang oleh pengusaha/eksportir batubara, sementara upaya pemerintah untuk menerapkan kebijakan pajak ekspor batubara selama ini belum berhasil. Keberhasilan dari penerapan pajak ekspor juga akan dipengaruhi tingkat harga batubara. Pajak ekspor yang tinggi akan "menghambat" ekspor, namun dalam jangka menengah-panjang dapat "memaksa" pengekspor untuk mengembangkan bisnis batubara di dalam negeri, dengan meningkatkan nilai tambah dari produk yang sebelumnya dieskpor sebagai bahan mentah. Pajak ekspor dimaksudkan untuk mengurangi ekspor batubara, bukan sebagai sumber tambahan penghasilan pemerintah dari pajak. Karena itu, meskipun tentangan dari kalangan pengusaha akan cukup besar (misalnya dengan alasan karena menurunkan minat investasi) hal ini penting untuk dilakukan.

\subsection{Kebijakan Pengurasan dan Pengendalian Produksi}

Kebijakan pengurasan (deletion policy) dapat digunakan untuk mengendalikan produksi, bermanfaat terhadap perlindungan lingkungan dan konservasi cadangan batubara nasional. Dari survei terhadap perizinan/kontrak pengusahaan batubara Indonesia, kami belum menemukan bahwa "kebijakan pengurasan" telah digunakan sebagai alat untuk membantu melakukan pengendalian produksi batubara. Sebaliknya, pengusaha pertambangan dapat saja melakukan eksploitasi besarbesaran dan secepat mungkin dari seluruh cadangan batubara dalam wilayah pertambangan yang dikuasainya, tanpa menyisakan ketersediaan cadangan batubara untuk pemakaian jangka panjang kemudian.

Kebijakan pengurasan lazimnya bertujuan untuk mengkonservasi sumberdaya alam, terutama sumber daya energi, untuk dapat digunakan lebih lama, termasuk menyediakannya untuk generasi mendatang. Selain untuk dapat menjamin kecukupan serta kualitas dari pasokan sumber daya energi ke depan, kebijakan pengurasan sumber daya alam/energi juga mempromosikan agar pemanfaatan sumber daya (yang telah dieksploitasi) dapat dilakukan secara efisien. Kebijakan pengurasan juga mempertimbangkan bahwa hal tersebut akan memberikan manfaat bagi perlindungan lingkungan, baik yang diterapkan dalam produksi maupun pemanfaatan sumberdaya alam. ${ }^{16}$

Kebijakan pengurasan dapat diterapkan pada Izin Usaha Pertambangan Batubara yang telah diberikan oleh pemerintah (Pusat maupun Daerah) dengan melakukan assessment terhadap rencana produksi yang diusulkan oleh perusahaan dan menyesuaikannya dengan "produksi yang dapat ditoleransi" (allowable production) yang ditetapkan oleh pemerintah (instansi pemberi izin). Pemerintah selaku instansi pemberi izin -berdasarkan kebijakan pengurasan yang dikembangkan-- seyogyanya telah menyiapkan besaran produksi yang diizinkan (baik untuk kurun selama kontrak atau dirinci ke periode-periode yang lebih pendek) sebelum Izin Usaha disepakati akan diberikan kepada suatu perusahaan tambang tertentu.

Pengendalian produksi dapat dilakukan dengan mulai menertibkan pemberian Izin Usaha Pertambangan, yang jumlahnya telah berkembang cukup besar (terutama Izin Usaha yang diberikan oleh Pemerintah Daerah). Izin Usaha -karena dari sini kegiatan eksploitasi bermula-- hanya dapat diberikan setelah melalui prosedur secara ketat, termasuk kelayakan dari Wilayah Pertambangan

${ }^{16}$ Sebagai contoh tentang kebijakan pengurasan dapat dilihat "National Depletion Policy 1980", Economic Planning Unit, Malaysia (www.epu.gov.my) 
tersebut sebelum ditawarkan. Disiplin dari Instansi Pemberi Izin (licensing grantor) juga sangat diperlukan untuk menjamin bahwa Izin Usaha yang diberikan akan diikuti dengan praktek penambangan yang baik (good mining practices) dan mengindahkan lingkungan.

Kebijakan pengurasan perlu segera diterapkan dalam pengelolaan industri pertambangan Indonesia untuk dapat melakukan pengendalian produksi sekaligus mencegah perusakan lingkungan terkait batubara.

\subsection{Aspek Ekonomi, Lingkungan, Infrastruktur}

Kegiatan produksi batubara Indonesia telah memberikan manfaat ekonomi baik kepada pengusaha pertambangan batubara maupun kepada Pemerintah Pusat yang bahkan telah menjadikan batubara sebagai salah satu sumber pendapatan APBN. Demikian pula, Pemerintah Daerah telah menjadikan "pendapatan batubara", baik dalam bentuk iuran tetap maupun Dana Bagi Hasil (DBH) sumber pendapatan bagi APBD.

Mengurangi produksi atau ekspor batubara dapat mengurangi sumber pendapatan APBN/APBD. Keuntungan yang berkurang dari pengusahaan batubara selain berdampak terhadap perusahaan batubara, dapat pula mengurangi pendapatan pajak pemerintah dari perusahaan batubara. Dampak tersebut akan terasa terutama dalam jangka pendek. Pemerintah (cq Kementerian Keuangan atau Dinas Pendapatan Daerah) akan menganggap pengurangan produksi batubara sebagai kebijakan yang tidak populer.

Namun demikian, dengan pertimbangan keamanan pasokan jangka panjang, upaya pengendalian produksi dan pembatasan ekspor tetap perlu dilakukan. Dari segi ekonomi, keamanan pasokan batubara jangka panjang akan membantu menumbuhkan kegiatan-kegiatan ekonomi, yang berarti juga meningkatkan pendapatan pemerintah (di antaranya dari pajak perusahaan industri). Batubara sendiri dapat diolah di dalam negeri (dibuat briket, digaskan, dicairkan, dsb.) untuk memberikan nilai tambah yang lebih tinggi. Keamanan pasokan batubara di dalam negeri akan memberikan keamanan pasokan listrik, menarik investasi bagi pengembangan industri. Bahwa pembatasan produksi/pengurangan ekspor batubara akan mengurangi pendapatan pemerintah dalam jangka pendek tidak perlu dikhawatirkan karena kehilangan tersebut akan dapat digantikan dengan pendapatan pemerintah dari pajak karena meningkatnya kegiatan industri/ ekonomi di dalam negeri dalam jangka menengah-panjang.

Pemakaian batubara sering dikaitkan dengan pencemaran lingkungan, terutama karena emisi $\mathrm{CO}_{2}$ yang dihasilkan dari pembakarannya. Beberapa kalangan menolak penggunaan batubara yang lebih besar di Indonesia.

Bahwa pemakaian batubara di PLTU berpotensi menghasilkan emisi $\mathrm{CO}_{2}$ yang cukup tinggi adalah benar, namun penting diperhatikan bahwa kapasitas PLTU yang telah dibangun di Indonesia relatif sangat kecil dibandingkan yang telah dibangun seperti di Jerman, Amerika Serikat, apalagi Cina. Emisi $\mathrm{CO}_{2}$ yang dihasilkan pun --untuk wilayah Indonesia yang luas-- relatif kecil dan jauh dari tingkat yang membahayakan.

Ke depan pemanfaatan teknologi batubara bersih di Indonesia akan lebih ditekankan. Misalnya, PLTU skala besar yang akan dibangun di Indonesia akan menggunakan teknologi ultra-supercritical (USC) yang lebih ramah lingkungan. Hal ini akan diikuti dengan teknologi ICCC (integrated gasification combined cycle) yang lebih bersih, bahkan pemanfaatan teknologi CCS (carbon capture \& storage). Teknologi batubara bersih berpotensi menghindarkan dampak buruk lingkungan dari pemanfaatan batubara; dan hal hal ini harus dikembangkan pemakaiannya. 
Indonesia juga diproyeksikan akan menggunakan banyak tambahan batubara, terutama untuk memasok pembangkit-pembangkit listrik yang kapasitasnya terus ditambah dan dibangun tersebar. Salah satu tantangan untuk membawa batubara dari lokasi-lokasi keterdapatannya yang sebagian besar di Kalimantan dan Sumatera ke lokasi-lokasi permintaannya, yang secara geografis terpisah jauh, adalah kesiapan sarana dan prasarana angkutan/penyimpanan batubara yang masih harus dikembangkan besar-besaran.

Pelabuhan batubara, fasilitas stockpiling dan blending serta penambahan armada pengangkutan (terutama kapal yang sekarang masih didominasi pemilikannya oleh perusahaan-perusahaan asing) merupakan bagian dari pembangunan sarana dan prasarana batubara yang masih harus dikembangkan untuk menyiapkan batubara sebagai tulang punggung energi nasional.

\section{Kesimpulan dan Rekomendasi}

\subsection{Kesimpulan}

i. Produksi batubara Indonesia meningkat pesat. Produksi yang besar $>400$ juta ton/ tahun) tidak seimbang dengan cadangan batubara Indonesia yang relatif kecil, sementara kebijakan untuk mengendalikan produksi belum dikembangkan.

ii. Ekspor batubara Indonesia sangat besar. Sekitar 80 persen dari produksi batubara Indonesia diekspor. Indonesia adalah pengekspor terbesar batubara dunia, anomali dibandingkan negara-negara yang memiliki cadangan serta produksi besar. PP 79/2014 tentang Kebijakan Energi Nasional mengamanatkan pembatasan ekspor.

iii. Produksi/ekspor batubara Indonesia memberikan manfaat ekonomi bagi pemerintah dan perusahaan batubara. Dalam jangka menengah-panjang, manfaat dari ekspor bahan mentah dapat digantikan dengan penciptaan nilai tambah di dalam negeri melalui pemanfaatan batubara untuk mengamankan pasokan energi serta pengubahannya untuk menciptakan nilai tambah lebih tinggi.

iv. Produksi dan pemanfaatan/pembakaran batubara membawa dampak negatip terhadap lingkungan. Dampak buruk pada lingkungan tersebut belum terlalu besar, mengingat volume pemanfaatan batubara di Indonesia yang belum banyak. Dampak buruk pada lingkungan dapat dikurangi melalui pemanfaatan teknologi bersih.

v. Sarana dan prasarana transportasi dan pemanfaatan batubara untuk kebutuhan dalam negeri di Indonesia masih sangat kurang, baik dibandingkan dengan perkembangan cepat dari permintaan batubara di dalam negeri (terutama untuk PLTU) nantinya, apalagi dibandingkan dengan prasarana dan sarana yang telah dikembangkan untuk mendukung ekspor batubara. Hal ini perlu diperbaiki.

vi. Kondisi ketahanan energi Indonesia kritis, dan batubara diharapkan dapat berfungsi sebagai tulang punggung pasokan energi nasional. Kebijakan mengenai pengendalian produksi, pembatasan ekspor, pengamanan pasokan dalam negeri, serta berbagai kebijakan lainnya menyangkut ekonomi, lingkungan dan infrastruktur perlu disusun untuk menyiapkan batubara menjalankan fungsinya sebagai tulang punggung pasokan energi nasional. 


\subsection{Rekomendasi}

1. Kembangkan/terapkan kebijakan pengurasan (depletion policy) untuk membantu mengendalikan produksi batubara, dan mencegah kerusakan lingkungan terkait penambangan batubara.

2. Pengendalian produksi perlu diterapkan sejak proses pemberian izin usaha pertambangan (licensing). Terapkan disiplin ketat dalam pemberian izin usaha pertambangan, baik izin yang diberikan oleh pemerintah pusat maupun daerah.

3. Kurangi ekspor batubara. Pengurangan ekspor batubara dapat dilakukan melalui penerapan pajak ekspor maupun dengan alasan bahwa batubara "dibutuhkan untuk mengamankan pasokan energi dalam negeri"

4. Kebijakan DMO (domestic market obligation) diarahkan untuk memenuhi kebutuhan/permintaan di dalam negeri sebagai prioritas pertama, dan bukan merupakan fungsi/persentase dari produksi.

5. Manfaatkan batubara sebagai energi untuk menggerakkan kegiatan-kegiatan dan memberi nilai tambah ekonomi di dalam negeri. Batubara mentah juga diproses lanjut di dalam negeri untuk memberikan nilai tambah lebih tinggi.

6. Perbanyak penerapan teknologi batubara bersih, tidak terbatas untuk PLTU namun juga pemakaian lain.

7. Perbaiki/percepat pembangunan sarana dan prasarana transportasi, penyimpanan, dan pemanfaatan batubara untuk melayani kebutuhan batubara dalam negeri. 


\section{Daftar Pustaka}

Ginandjar Kartasasmita, 2012. Ketahanan dan Kemandirian Energi: Sebuah Tinjauan Mengenai Potensi Batubara Sebagai Tulang Punggung Energi Indonesia di Masa Mendatang. Jakarta, Dewan Pertimbangan Presiden.

Hanan Nugroho, 2014. Ketahanan Energi Indonesia: Gambaran Permasalahan dan Strategi Memperbaikinya. Majalah/Jurnal Perencanan Pembangunan No. 3/2014.

Hanan Nugroho, 2011. A Mosaic of Indonesian Energy Policy. IPB Press.

Hanan Nugroho, 2012. Energi dalam Perencanaan Pembangunan. IPB Press.

Tim Analisis Kebijakan, 2015. Menyiapkan Batubara Sebagai Tulang Punggung Pasokan Energi Nasional. BAPPENAS.

Tim Analisis Kebijakan, 2014. Memperbaiki Ketahanan Energi Indonesia: Rekomendasi Strategi dan Analisis. BAPPENAS. 